ISSN (print): 2715-3177 | ISSN (online): 2614-8102

Program Studi Ekonomi Syariah, STAI Auliaurrasyidin Tembilahan Journal Homepage: https://ejournal.stai-tbh.ac.id/index.php/al-muqayyad

\title{
Pengaruh Religiositas terhadap Minat Mahasiswa Menabung di Bank Syariah
}

\author{
*Peni Darmisah ${ }^{1, a}$, Saiin Saiin ${ }^{2, b}$
}

${ }^{1,2)}$ STAI Auliaurrasyidin Tembilahan, Indragiri Hilir, Riau, Indonesia Email: ${ }^{a}$ penidarmisah151@gmail.com; ${ }^{\mathrm{b}}$ saiin@ @ stai-tbh.ac.id; ${ }^{\mathrm{c}}$

\begin{tabular}{|c|c|}
\hline DOI: & Cara Mensitasi Artikel ini: \\
\hline$\frac{\text { https://doi.org/10.469 }}{\text { 63/jam.v4i1.339 }}$ & $\begin{array}{l}\text { Darmisah. P., \& Saiin, S. (2021). Pengaruh religiositas terhadap minat mahasiswa } \\
\text { menabung di Bank Syariah. AL-Muqayyad, 4(1), 25-35. } \\
\text { https://doi.org/10.46963/jam.v4i1.339 }\end{array}$ \\
\hline
\end{tabular}

Keywords: Religiosity, Interest, Saving

\section{Kata Kunci:} Religiositas, Minat, Menabung

\section{Informasi Artikel:}

Diterima:

09/06/2021

Direvisi:

-

Diterbitkan $30 / 06 / 2021$

\section{*Corresponding}

Author

penidarmisah151@g $\underline{\text { mail.com }}$

\section{ABSTRACT}

As students who have an educational background in Islamic Economics, each has a different perception of Islamic Banking. There are still students who compare Islamic banks and conventional banks, a doubt toward the operational saving system, financing or discounting, and the existence of conventional Banks being more affordable than Islamic banks in remote areas. This study aimed to examine the effect of religiosity on students' interest in saving in Islamic banks. This type of research was quantitative with data analysis using a simple regression method. The results showed that the tcount was 14,832, and the $t$ table was $1,975<t$ count 14,832 with a significance of 0.000 under 0.05 . Therefore, it concluded that religiosity significantly affects the saving interest of students at Islamic Banks.

\section{ABSTRAK}

Sebagai mahasiswa yang memiliki latar belakang pendidikan Ekonomi Syariah, masing-masing mempunyai persepsi yang berbeda terhadap Perbankan Syariah. Masih ada mahasiswa yang membandingkan antara Bank Syariah dan Bank Konvensional. keraguan antara sistem operasional dalam menabung, pembiayaan atau potongan, dan keberadaan Bank Konvensional lebih terjangkau dibandingkan Bank Syariah di daerah yang terpencil. Penelitian ini bertujuan untuk mengetahui pengaruh religiositas terhadap minat menabung di Bank Syariah. Jenis penelitian ini adalah penelitian kuantitatif dengan metode analisis data menggunakan metode regresi sederhana. Hasil analisa menunjukkan nilai $t$ hitung sebesar 14,832 sehingga t tabel 1,975 < $t$ hitung 14,832 dengan signifikansi 0,000 di bawah dari 0,05, dengan demikian, dapat disimpulkan bahwa religiusitas secara signifikan berpengaruh terhadap minat menabung mahasiswa Program Studi Ekonomi Syariah di Bank Syariah.

\section{PENDAHULUAN}

Perbankan adalah lembaga yang mempunyai peran utama dalam pembangunan suatu negara. Peran ini terwujud dalam fungsi bank sebagai lembaga intermediasi keuangan (Financial Intermediary Institution), yakni menghimpun dana dari masyarakat dalam bentuk simpanan dan menyalurkan kepada masyarakat dalam bentuk kredit atau bentuk-bentuk lainnya dalam rangka meningkatkan taraf hidup rakyat. Perbankan syariah merupakan institusi yang memberikan layanan jasa perbankan berdasarkan prinsip syariah. Prinsip syariah adalah prinsip hukum Islam dalam kegiatan perbankan 
Peni Darmisah; \& Saiin Saiin

berdasarkan fatwa yang dikeluarkan oleh lembaga yang memiliki kewenangan dalam penetapan fatwa di bidang syariah. Prinsip ini menggantikan prinsip bunga yang terdapat dalam sistem perbankan konvensional (Totok Budisantoso, 2017).

Prinsip utama operasional bank yang berdasarkan pada prinsip syariah adalah hukum Islam yang bersumber dari Al-Quran dan Al-Hadis. Kegiatan operasional bank harus memperhatikan perintah dalam Al-Quran dan Sunah Rasul Muhammad SAW. Larangan terutama berkaitan dengan kegiatan bank yang dapat diklasifikasikan sebagai riba (Totok Budisantoso, 2017). Islam tidak menyukai umatnya melakukan riba, bagi seorang muslim yang melakukan riba adalah haram hukumnya (Irham Fahmi, 2014). Allah SWT dalam Al-Quran berfirman:

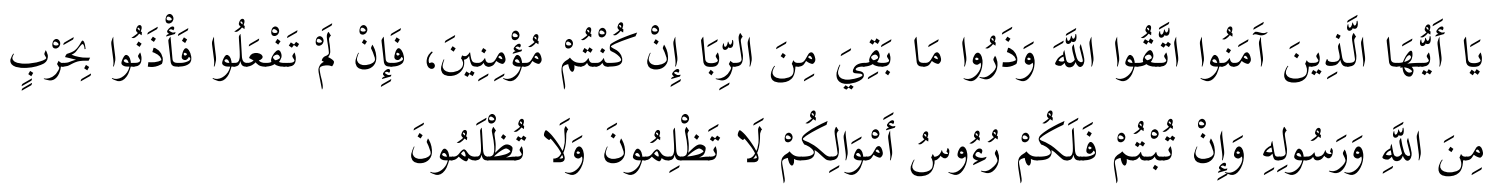

Artinya: "Hai orang-orang yang beriman, bertakwalah kepada Allah dan tinggalkan sisa Riba (yang belum dipungut) jika kamu orang-orang yang beriman. Maka jika kamu tidak mengerjakan (meninggalkan sisa riba), Maka ketahuilah, bahwa Allah dan Rasul-Nya akan memerangimu. dan jika kamu bertobat (dari pengambilan riba), Maka bagimu pokok hartamu; kamu tidak Menganiaya dan tidak (pula) dianiaya." (QS. Al-Baqarah: 278-279)

Karakteristik sistem perbankan syariah yang beroperasi berdasarkan prinsip bagi hasil memberikan alternatif sistem perbankan yang saling menguntungkan bagi masyarakat dan bank, serta menonjolkan aspek keadilan dalam bertransaksi, investasi yang beretika, mengedepankan nilai-nilai kebersamaan dan persaudaraan dalam berproduksi, dan menghindari kegiatan spekulatif dalam bertransaksi keuangan (Julius R. Latumaerissa, 2013).

Dengan lahirnya bank Islam yang beroperasi berdasarkan sistem bagi hasil sebagai pengganti dari bunga pada bank-bank konvensional, menjadikan peluang bagi umat Islam untuk memanfaatkan jasa bank seoptimal mungkin. Hubungan antara umat muslim dengan perbankan dapat menjadi tenang tanpa adanya keraguan dan tentunya didasari oleh motivasi keagamaan yang kuat.

Saat ini sebagian besar masyarakat hanya melihat bahwa nilai tambah bank syariah adalah lebih halal dan selamat, lebih menjanjikan untuk kebaikan akhirat, dan juga lebih berorientasi pada menolong antar sesama dibandingkan dengan bank Al-Muqayyad

Vol. 4 No. 1 (2021) 
Pengaruh Religiositas terhadap Minat Mahasiswa Menabung di Bank Syariah

konvensional. Hal tersebut memang benar, namun bank syariah memiliki keuntungan duniawi karena produk-produknya tidak kalah bersaing dengan bank-bank konvensional dan juga bagi hasil yang ditawarkan tidak kalah menguntungkan dibandingkan dengan bunga. Peranan bank konvensional yang telah berdiri lebih dahulu dibandingkan bank syariah, sudah memenuhi kebutuhan masyarakat dalam melakukan transaksi perbankan.

Hal ini menjadikan sebagian masyarakat muslim sudah menggunakan jasa bank konvensional, karena bank konvensional dianggap memiliki fasilitas yang lebih lengkap, dan cabang yang lebih tersebar di sebagian penjuru kota di Indonesia. Adanya bank syariah di Indonesia menjadi pilihan bagi sebagian umat muslim di Indonesia untuk menggunakan jasa perbankan syariah, namun masih banyak yang tetap menggunakan bank konvensional dengan berbagai pertimbangan.

Dengan latar belakang pendidikan Ekonomi syariah, dari masing-masing mahasiswa mempunyai persepsi berbeda dalam memandang perbankan syariah. Dari keseluruhan jumlah mahasiswa jurusan ekonomi syariah mempunyai kecenderungan yang berbeda pula dalam memilih dan menggunakan jasa perbankan syariah, dengan berbagai alasan masing-masing. Pengetahuan mahasiswa jurusan ekonomi syariah bisa menjadikan minat menabung di perbankan syariah sangatlah besar. Mereka lebih mengetahui bagaimana sistem ataupun operasional dari perbankan syariah melalui ranah pendidikan dan aplikasi mereka dengan menjadi salah satu nasabah di perbankan syariah, serta produk-produk unggulan yang dimiliki bank syariah.

Berbagai alasan yang memicu mahasiswa enggan menabung di Bank Syariah, sebagian merupakan alasan dari dalam diri dan sebagian lagi merupakan alasan dari luar. Alasan dari dalam misalnya sikap mahasiswa terhadap bank syariah dan religiositas mahasiswa. Mahasiswa merasa malas menabung, meskipun pada dasarnya mereka berminat. Hal ini merupakan contoh sikap mahasiswa terhadap bank syariah. Kemudian yang berkaitan dengan religiositas mahasiswa yaitu adanya keraguan mengenai praktik bank syariah apakah sudah sesuai dengan syariat Islam atau belum. Sedangkan alasan dari luar berasal dari bank syariah sendiri. Kesulitan akses menjangkau misalnya. Jika dibandingkan dengan bank konvensional, informasi mengenai bank syariah memang cenderung lebih terbatas. 
Peni Darmisah; \& Saiin Saiin

\section{METODE}

Jenis penelitian ini adalah penelitian kuantitatif. Metode penelitian kuantitatif dapat diartikan sebagai metode penelitian yang berlandaskan pada filsafat positivisme, digunakan untuk meneliti pada populasi atau sampel tertentu, pengumpulan data menggunakan instrumen penelitian, analisis data bersifat kuantitatif/statistik, dengan tujuan untuk menguji hipotesis yang telah ditetapkan (Sugiyono, 2016).

Dalam penelitian ini menjelaskan tentang pengaruh religiositas terhadap minat menabung di Bank Syariah (Studi kasus mahasiswa program studi ekonomi syariah STAI Auliaurrasyidin Tembilahan).

Populasi dalam penelitian ini adalah mahasiswa Program Studi Ekonomi Syariah STAI Auliaurrasyidin Tembilahan angkatan 2016-2019 yang berjumlah 399 mahasiswa. Sampel yang digunakan dalam penelitian ini adalah probability sampling dengan spesifikasi teknik sampling menggunakan Simple Random Sampling. Penarikan jumlah sampel dengan menggunakan tabel Isaac dan Michael dari populasi 399 mahasiswa dengan taraf kesalahan 10\% dengan jumlah sampel sebanyak 158 mahasiswa.

Dalam penelitian ini, penulis menggunakan kuesioner dan dokumentasi sebagai teknik pengumpulan data. Pernyataan yang diberikan kepada responden dengan memilih salah satu alternatif jawaban dari setiap pernyataan yang telah tersedia dengan menggunakan skala pengukuran yaitu skala pengukuran likert dengan alternatif penilaian 1 sampai 5 kategori yang mempunyai gradasi positif.

Teknik analisis data yang digunakan yaitu menggunakan regresi linier sederhana yaitu suatu formula yang mencari nilai variabel dependen dari nilai variabel dependen yang diketahui.

\section{HASIL DAN PEMBAHASAN}

Analisis data yang diperoleh dalam penelitian ini menggunakan kuesioner (angket) yang telah disebarkan dan diisi langsung oleh responden sebanyak 158 mahasiswa Program Studi Ekonomi Syariah STAI Auliaurrasyidin Tembilahan. Setelah seluruh kuesioner (angket) selesai diisi selanjutnya data diolah dengan hasil sebagai berikut:

\section{Al-Muqayyad}

Vol. 4 No. 1 (2021) 
Pengaruh Religiositas terhadap Minat Mahasiswa Menabung di Bank Syariah

\section{Uji validitas}

Uji validitas digunakan untuk mengetahui butir item yang valid dan tidak valid dengan membandingkan nilai $t_{\text {hitung }}$ lebih besar dari $t_{\text {tabel }}$ dengan nilai taraf signifikan $<$ $0,05(5 \%)$. Hasil uji validitas dapat dilihat dari hasil olahan data dar SPSS berikut ini:

Tabel. I

Hasil Uji Validitas Variabel Religiositas (X)

\begin{tabular}{ccccc}
\hline Butir & $\begin{array}{c}\text { Nilai Corrected Item } \\
\text { Total Correlation/ } \mathbf{r}_{\text {hitung }}\end{array}$ & Sig. & $\mathrm{r}_{\text {tabel }}$ & Keterangan \\
\hline 1 & 0,574 & 0,000 & 0,1562 & Valid \\
2 & 0,574 & 0,000 & 0,1562 & Valid \\
3 & 0,797 & 0,000 & 0,1562 & Valid \\
4 & 0,929 & 0,000 & 0,1562 & Valid \\
5 & 0,913 & 0,000 & 0,1562 & Valid \\
6 & 0,913 & 0,000 & 0,1562 & Valid \\
7 & 0,908 & 0,000 & 0,1562 & Valid \\
8 & 0,674 & 0,000 & 0,1562 & Valid \\
9 & 0,584 & 0,000 & 0,1562 & Valid \\
10 & 0,556 & 0,000 & 0,1562 & Valid \\
\hline
\end{tabular}

Sumber Data: Hasil olahan SPSS

Berdasarkan output di atas, maka dapat dilihat bahwa seluruh pernyataan untuk variabel religiositas dinyatakan valid karena nilai $r_{h i t u n g}>r_{\text {tabel }}$ sebesar 0,1562 dengan taraf signifikan 0,000 <0,05 $(5 \%)$.

Tabel. 2

Hasil Uji Validitas Variabel Minat Menabung (Y)

\begin{tabular}{ccccc}
\hline Butir & $\begin{array}{c}\text { Nilai Corrected Item } \\
\text { Total Correlation/ritung }\end{array}$ & Sig. & $\mathrm{r}_{\text {tabel }}$ & Keterangan \\
\hline 1 & 0,885 & 0,000 & 0,1562 & Valid \\
2 & 0,917 & 0,000 & 0,1562 & Valid \\
3 & 0,787 & 0,000 & 0,1562 & Valid \\
4 & 0,867 & 0,000 & 0,1562 & Valid \\
5 & 0,789 & 0,000 & 0,1562 & Valid \\
6 & 0,861 & 0,000 & 0,1562 & Valid \\
7 & 0,866 & 0,000 & 0,1562 & Valid \\
8 & 0,813 & 0,000 & 0,1562 & Valid \\
9 & 0,877 & 0,000 & 0,1562 & Valid \\
10 & 0,841 & 0,000 & 0,1562 & Valid \\
\hline
\end{tabular}

Sumber Data: Hasil Olahan SPSS

Al-Muqayyad

Vol. 4 No. 1 (2021) 
Peni Darmisah; \& Saiin Saiin

Berdasarkan output di atas, maka dapat dilihat bahwa seluruh pernyataan untuk variabel minat menabung mahasiswa dinyatakan valid karena nilai $r_{h i t u n g}>r_{\text {tabel }}$ sebesar 0,1562 dengan taraf signifikan $0,000<0,05(5 \%)$.

\section{Uji Reliabilitas}

Uji reliabilitas dilakukan untuk mengukur sejauh mana pengukuran itu menjamin suatu item pernyataan yang konsisten.

Dalam hasil penelitian melalui program SPSS 22.0, pengujian reliabilitas ini menggunakan metode alpha cronbach's yang di mana satu kuesioner di anggap reliabel apabila cronbach's alpha $>0,600$. Hasil pengolahan data uji reliabilitas berikut ini:

Tabel. 3

Hasil Uji Reliabilitas

\begin{tabular}{clccc}
\hline No & \multicolumn{1}{c}{ Variabel } & $\mathrm{r}_{\text {alpha }}$ & $\mathrm{r}_{\text {kritis }}$ & Keterangan \\
\hline 1 & Religiusitas & 0,801 & 0,600 & Reliabel \\
2 & Minat Menabung & 0,757 & 0,600 & Reliabel \\
\hline
\end{tabular}

Sumber Data : Hasil olahan SPSS

Dari hasil output di atas, hasil koefisien reliabilitas religiositas adalah sebesar 0,801 dan minat menabung sebesar 0,757 ternyata lebih besar dari nilai Alpha Cronbach dari 0,600, yang berarti kedua instrumen dinyatakan reliabel atau telah memenuhi syarat.

1. Koefesien determinasi $\left(\mathrm{R}^{2}\right)$

Diketahui uji koefisien (Uji $\mathrm{R}^{2}$ ) digunakan untuk mengetahui seberapa jauh pengaruh dari kontribusi variabel independen terhadap variabel dependen. Nilai $R$ Square sebesar 0,585. Nilai ini mengandung arti bahwa pengaruh religiositas (X) terhadap minat menabung (Y) mahasiswa adalah sebesar 58,5\% sedangkan sisanya yaitu 41,5\% dipengaruhi oleh variabel lain di luar dari pembahasan yang diteliti.

2. Uji T

Uji T menunjukkan seberapa jauh pengaruh variabel independen terhadap variabel dependen, dengan kriteria pengujian jika $t_{\text {hitung }}>t_{\text {tabel }}$ atau nilai probabilitas sig < a maka Ho ditolak. Nilai thitung sebesar 14,832 dengan nilai signifikan sebesar 0,000. Dikarenakan nilai thitung lebih besar dari nilai tabel dan nilai probabilitas sig lebih kecil dari pada 0,05, sehingga dapat disimpulkan bahwa Ho ditolak dan $\mathrm{Ha}$ 
Pengaruh Religiositas terhadap Minat Mahasiswa Menabung di Bank Syariah

diterima. Yang berarti bahwa "Ada Pengaruh Religiositas (X) yang signifikan terhadap Minat Menabung (Y) mahasiswa di Bank Syariah".

Hasil uji regresi pengaruh religiositas terhadap minat menabung menunjukkan bahwa variabel religiositas berpengaruh positif secara signifikan pada variabel minat menabung di Bank Syariah. Hasil ini didapatkan dari hasil penelitian yang telah diolah menggunakan analisis regresi sederhana yang dibantu dengan program software SPSS 22.0 dengan hasil olah data sebagai berikut:

Tabel. 4

Hasil Output Estimasi Regresi

Coefficients $^{\mathbf{a}}$

\begin{tabular}{|c|c|c|c|c|c|}
\hline \multirow[b]{2}{*}{ Model } & \multicolumn{2}{|c|}{$\begin{array}{l}\text { Unstandardized } \\
\text { Coefficients }\end{array}$} & \multirow{2}{*}{$\begin{array}{c}\begin{array}{c}\text { Standardized } \\
\text { Coefficients }\end{array} \\
\text { Beta }\end{array}$} & \multirow[b]{2}{*}{$\mathrm{T}$} & \multirow[b]{2}{*}{ Sig. } \\
\hline & B & Std. Error & & & \\
\hline 1 (Constant) & 2.316 & 2.808 & & .825 & .411 \\
\hline Religiusitas & .922 & .062 & .765 & 14.832 & .000 \\
\hline
\end{tabular}

a. Dependent Variable: Minat Menabung

Sumber Data: Hasil olahan SPSS

Dari output di atas, diketahui $\mathrm{a}=$ angka konstan dari unstandardized ciefficients dalam kasus ini nilainya sebesar 2,316. Angka ini merupakan angka konstan yang mempunyai arti bahwa jika tidak ada religiositas (X) maka nilai konsisten Minat Menabung (Y) mahasiswa adalah sebesar 2,316. Sedangkan $b=$ angka koefisien regresi. Nilainya sebesar 0,922. Angka ini mengandung arti bahwa setiap penambahan $1 \%$ religiositas (X) maka minat menabung (Y) akan meningkat sebesar 0,922.

Karena nilai koefisien regresi bernilai positif (+), maka dengan demikian dapat dikatakan bahwa religiositas (X) berpengaruh positif terhadap minat menabung (Y), sehingga semakin tinggi religiositas mahasiswa maka semakin meningkat minat menabung mahasiswa di Bank Syariah.

Teori-teori dalam penelitian yaitu tentang religiositas dan minat menabung:

1. Religiositas

a. Pengertian religiositas

Religiositas dalam kamus lengkap psikologi yaitu berasal dari kata religion (agama). Religion (agama) adalah suatu sistem yang kompleks dari kepercayaan, 
Peni Darmisah; \& Saiin Saiin

keyakinan, sikap-sikap, dan upacara-upacara yang menghubungkan individu dengan suatu keberadaan atau makhluk yang bersifat ketuhanan (James P Chaplin, 2006).

b. Fungsi agama (religius) bagi manusia

Menurut Hendropuspito (1990) fungsi agama bagi manusia meliputi beberapa hal diantaranya:

1) Fungsi edukatif

2) Fungsi penyelamatan

3) Fungsi pengawasan sosial

4) Fungsi memupuk persaudaraan

5) Fungsi transformatif

c. Dimensi religiositas

Menurut Glock dan Stark, ada lima macam dimensi keberagamaan, yaitu:

1) Dimensi keyakinan

2) Dimensi praktik agama

3) Dimensi pengalaman

4) Dimensi pengetahuan agama

5) Dimensi pengamalan atau konsekuensi (Djalamudin Ancok dan Fuad Nashori Suroso, 2011).

2. Minat Menabung

a. Pengertian minat

Minat (interest), istilah ini menunjuk pada adanya Intensitas perhatian yang tinggi seseorang terhadap suatu hal peristiwa, orang atau benda (Fuad Hasan, dkk, 2003).

b. Dimensi minat

Minat dapat diidentifikasikan melalui indikator-indikator sebagai berikut :

1) Minat transaksional

2) Minat refrensional

3) Minat prefrensi

4) Minat eksploratif (Augusty Ferdinand, 2006). 
Pengaruh Religiositas terhadap Minat Mahasiswa Menabung di Bank Syariah

c. Pengertian menabung

Menabung adalah tindakan yang dianjurkan oleh islam, karena dengan menabung berarti seorang muslim mempersiapkan diri untuk pelaksanaan perencanaan masa yang akan datang sekaligus untuk menghadapi hal-hal yang tidak diinginkan. Dalam Al-qur'an terdapat ayat-ayat yang secara tidak langsung telah memerintahkan kaum muslimin untuk mempersiapkan hari esok secara lebih baik (Muhammad Syafi'I Antonio, 2001).

d. Beberapa jenis tabungan di Bank Syariah Memilih antara Wadiah dan Mudharabah

1) Giro

2) Tabungan

3) Deposito (Muhammad Syafi'I Antonio, 2001).

e. Perbedaan antara menabung Bank Syariah dan Bank Konvensional

Sepintas, secara teknis fisik, menabung di bank syariah dengan yang berlaku di bank konvensional hampir tidak ada perbedaan. Hal ini karena baik bank syariah maupun bank konvensional diharuskan mengikuti aturan teknis perbankan secara umum. Akan tetapi, jika diamati secara mendalam, terdapat perbedaan besar di antara keduanya. Perbedaan pertama terletak pada akad, perbedaan kedua terdapat pada imbalan yang diberikan, perbedaan ketiga adalah sasaran kredit/pembiayaan (Muhammad Syafi'I Antonio, 2001).

\section{SIMPULAN}

Berdasarkan uraian yang telah peneliti paparkan terhadap data yang telah terkumpul dan kemudian diolah, mengenai pengaruh religiositas terhadap minat menabung mahasiswa di Bank Syariah, maka peneliti dapat mengambil beberapa kesimpulan sebagai jawaban dari pertanyaan rumusan masalah yang menjadi tujuan dalam penelitian ini antara lain sebagai berikut:

Terdapat pengaruh signifikan dan positif antara religiositas terhadap minat menabung mahasiswa program studi ekonomi syariah di Bank Syariah. Hal ini dibuktikan dengan hasil model persamaan regresi $\widehat{Y}=2,316+0,922 \mathrm{X}$ dimana setiap angka penambahan $1 \%$ pada religiusitas (X) maka minat menabung (Y) akan meningkat sebesar 0,922, kemudian di uji melalui Uji $\mathrm{R}^{2}$ dengan nilai sebesar 0,585 (persentase 58,5\%), Uji 
Peni Darmisah; \& Saiin Saiin

F dengan diperoleh nilai $F_{\text {hitung }}$ sebesar 219,977 $>F_{\text {tabel }}(3,90)$ dengan nilai signifikannya sebesar 0,000 pada tingkat signifikan 0,05 dengan model regresi yang dipilih adalah tepat, dan Uji T yang menunjukkan pengaruh positif dengan nilai $t_{\text {hitung }}>$ dari $t_{\text {tabel }}$ yaitu 14,832 $>$ 1,975 dengan nilai signifikansi sebesar 0,000 ( $\mathrm{Sig}<0,05)$. Sehingga diperoleh Ho ditolak dan Ha diterima artinya variabel religiositas mempunyai pengaruh yang signifikan terhadap minat menabung mahasiswa program studi ekonomi syariah.

\section{REFERENSI}

Ali, M. D. (2016). Pendidikan Agama Islam. Jakarta: Rajawali Pers.

Ancok, D., \& Suroso, F. N. (2011). Psikologi Islami. Yogyakarta: Pustaka Pelajar.

Antonio, M. S. (2001). Bank Syariah Dari Teori ke Praktik. Jakarta: Gema Insani Press.

Arif, M. N., Rianto A. (2012). Dasar-Dasar Pemasaran Bank Syariah. Bandung: Alfabeta.

Arifin, B. S. (2015). Psikologi Agama. Bandung: CV Pustaka Setia.

Astuti, T., \& Mustikawati, R. I. (2013). Pengaruh persepsi nasabah tentang tingkat suku bunga, promosi dan kualitas pelayanan terhadap minat menabung nasabah. Nominal: Barometer Riset Akuntansi dan Manajemen, 2(1), 182-198. https://doi.org/10.21831/nominal.v2i1.1655

Azis, M. A. (2019). Analisis Faktor-Faktor Yang Mempengaruhi Minat Menabung Di Bank Syariah". Skripsi, Salatiga: IAIN Salatiga.

Aziz, A. (2010). Manajemen Investasi Syariah. Bandung: Alfabeta.

Bugin, B. (2010). Metodologi Penelitian Kuantitatif. Jakarta: Pranada Media Groub.

Chaplin, James P. (2006). Kamus Lengkap Psikologi. Jakarta: PT Raja Grafindo Persada.

Departemen Agama RI. (2008). Al-Quran dan Terjemahnya. Bandung: CV Diponegoro.

Fahmi, Irham. (2014). Pengantar Perbankan Teori \& Aplikasi. Bandung: Alfabeta.

Ferdinand, Augusty. (2006). Metode Penelitian Manajemen. Semarang: Badan Penerbit Universitas Diponegoro.

Hasan, Fuad, dkk. (2003). Kamus Istilah Psikologi. Jakarta: Progres.

Ismail. (2013). Perbankan Syariah. Jakarta: Kencana.

Jamaludin, A. N. (2015). Agama dan Konflik Sosial. Bandung: CV Pustaka Setia.

Kristiyadi, K., \& Hartiyah, S. (2017). Pengaruh kelompok acuan, religiusitas, promosi dan pengetahuan tentang lembaga keuangan syariah terhadap minat menabung di koperasi jasa keuangan syariah (Studi Kasus pada BMT TAMZIS Wonosobo). Jurnal Ekonomi dan Teknik Informatika, 4(2), 44-63.

Kuncoro, M. (2013). Metode Riset untuk Bisnis \& Ekonomi. Edisi 4. Jakarta: Erlangga.

\section{Al-Muqayyad}

Vol. 4 No. 1 (2021) 
Pengaruh Religiositas terhadap Minat Mahasiswa Menabung di Bank Syariah

Latumaerissa, J. R. (2013). Bank dan Lembaga Keuangan Lain. Jakarta: Salemba Empat. Muhaimin. (2014). Studi Islam Dalam ragam Dimensi dan Pendekatan. Jakarta: Kencana. Puspito, H. (1990). Sosiologi Agama. Yogyakarta: Kanisus dan BPK Gunung Mulia.

Rusdianto, H., \& Ibrahim, C. (2016). Pengaruh Produk Bank Syariah Terhadap Minat Menabung Dengan Persepsi Masyarakat Sebagai Variabel Moderating Di Pati. Equilibrium: Jurnal Ekonomi Syariah, 4(1), 43-61. http://dx.doi.org/10.21043/equilibrium.v4i1.1837

Santoso, S. (2014). SPSS From Essential to Expert Skilss. Jakarta: PT Elex Media Komputindo.

Sugiyono. (2016). Metode Penelitian Kuantitatif Dan Kualitatif, Dan R\&D. Bandung: Alfabeta.

Sugiyono. (2016). Metode Penelitian Manajemen. Bandung: Alfabeta 